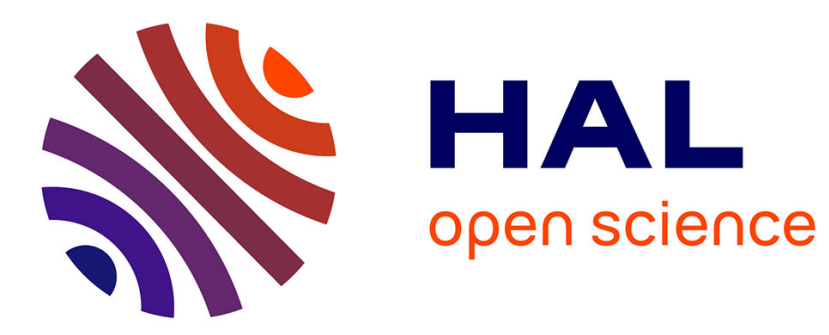

\title{
Is the workplace a site of cardiac arrest like any other?
}

\author{
Alexis Descatha, Daniel Jost, Jean-Pierre Carpentier
}

\section{To cite this version:}

Alexis Descatha, Daniel Jost, Jean-Pierre Carpentier. Is the workplace a site of cardiac arrest like any other?. Resuscitation, 2009, 80 (5), pp.602-3. 10.1016/j.resuscitation.2009.01.018 . inserm-00372505

\section{HAL Id: inserm-00372505 https://www.hal.inserm.fr/inserm-00372505}

Submitted on 1 Apr 2009

HAL is a multi-disciplinary open access archive for the deposit and dissemination of scientific research documents, whether they are published or not. The documents may come from teaching and research institutions in France or abroad, or from public or private research centers.
L'archive ouverte pluridisciplinaire HAL, est destinée au dépôt et à la diffusion de documents scientifiques de niveau recherche, publiés ou non, émanant des établissements d'enseignement et de recherche français ou étrangers, des laboratoires publics ou privés. 
Is the workplace a site of cardiac arrest like any other?

Alexis Descatha ${ }^{2}$, Daniel Jost ${ }^{1}$, Jean-Pierre Carpentier ${ }^{1}$

1 Paris Fire Brigade (Brigade des Sapeurs Pompiers de Paris), Paris, France

2 UVSQ, Occupational health unit/ INSERM U687/EMS92 (Unité de pathologie professionnelle/INSERMU687/SAMU 92), Raymond Poincare Teaching Hospital,AP-HP, Garches, France

\section{Corresponding author:}

Dr. Alexis Descatha - Unité de pathologie professionnelle/INSERM U687/SAMU 92. CHU Raymond Poincaré 104 Bd Poincaré, F-92380 Garches, France

alexis.descatha@rpc.aphp.fr

Phone: +33147107754 Fax: +33147107768

All authors declare that they participated in the study (conception, analyses, writing and correction), drafting the article or revising it critically for important intellectual content, and that they have seen and approved the final version.

All the persons named in the Acknowledgments section have provided the corresponding author with written permission to be named in the manuscript.

No authors have any conflicts of interest.

Ethics committee obtained ("CNIL")

No copyright constraints.

No prior or duplicate publication or submission had been made elsewhere

Manuscript type: letter to editor

Word count $=473$ words, 5 references, 1 table, 5 pages $($ all included $)$ 
Although the installation of automated external defibrillators (AED) in public places is still the subject of controversy (1), only very limited data are available on the management of outof-hospital cardiac arrest (OHCA) in the workplace (2).

The objective of this study was to identify the frequency of OHCA in the workplace in a Paris register of all OHCAs. The characteristics of the chain of survival of workplace OHCA was compared to that of other sites of OHCA.

The 2004 data of the OHCA prospective register managed by the Paris Fire Brigade (including all OHCA managed by Firemen in Paris and the inner suburbs) were analyzed by distinguishing OHCA in the workplace from OHCA in other sites. The criterion of survival was restoration of circulation allowing hospital admission determined by the emergency physician of the prehospital care unit. Age, gender and certain elements characterizing the chain of survival were prospectively collected for univariate and multivariate comparisons according to the site of OHCA.

In 2004, 2,717 OHCAs were managed in Paris and the inner suburbs, but data of location were missing for 416 cases (15.3\%). Of the 2,301 OHCAs studied, $61(2.7 \%)$ occurred in the workplace. Restoration of circulation allowing hospital admission was observed in 19/61 $(31.1 \%)$ of these cases by the emergency physician of the prehospital care unit, which was significantly higher than for other sites of OHCA $(\mathrm{n}=438 / 2,240,20.0 \%$, OR crude $=1.9[1.1$ 3.2]). Age and certain parameters of the chain of survival differed significantly in the workplace than outside (Table 1). When these parameters were taken into account the link between workplace and restoration of circulation was no longer observed ( $\mathrm{OR}_{\text {adjusted }}=1.0[0.6-$ $1.8])$. 
OHCA in the workplace appears to be rare $(<3 \%)$, but is associated with a better immediate prognosis than OHCA in other places. This is probably related to a more effective chain of survival and a healthy worker effect.

Although this study presents limitations due to missing data (incomplete data, low rate of OHCA managed by volunteer first-aid workers not included) and unavailable variables (time to alert or cardiac massage, long-term survival data), these results are coherent with the rare studies specifically devoted to this subject (2-5) with a similar proportion of OHCA occurred in the workplace ( 1 to $6 \%$ of the OHCA).

Despite its relatively low incidence, OHCA in the workplace appears to be managed more effectively than OHCA occurring in other places, which encourages the setting up of first-aid programmes in certain companies. Further studies will be necessary to evaluate the benefits and the cost of this workplace health policy.

\section{Acknowledgments}

We would like to thank H. Degrange, S. Dubourdieu, J.L. Petit, and the Cardiac Arrest Working group of the Paris Fire Brigade (Doctors F. Briche, D. Fontaine, S. Dubourdieu, O. Hersan, S. Travers, A. Renard, D. Lallement, F. Calamai).

\section{Conflict of interest statement}

None. 


\section{References}

1. Hallstrom AP, Ornato JP, Weisfeldt M, et al. Public-access defibrillation and survival after out-of-hospital cardiac arrest. N.Eng1.J.Med. 2004;351:637-46.

2. Descatha A, Baer M. Automated external defibrillators in the workplace. BMJ 2008;337(oct08_1):a1816.

3. Engdahl J, Herlitz J. Localization of out-of-hospital cardiac arrest in Goteborg 19942002 and implications for public access defibrillation. Resuscitation 2005;64:171-5.

4. Muraoka H, Ohishi $\mathrm{Y}$, Hazui H, et al. Location of out-of-hospital cardiac arrests in Takatsuki City: where should automated external defibrillator be placed. Circ.J. $2006 ; 70: 827-31$

5. Descatha A, Frederic M, Devere C, et al. Details of the initial management of cardiac arrest occurring in the workplace in a French urban area. Resuscitation 2005;65:301-7. 
Table 1: Comparison of characteristics (age, gender, some parameters of the chain of survival) of out-of-hospital cardiac arrest (OHCA) in the workplace and outside of the workplace (multivariate analysis by logistic regression)

\begin{tabular}{|c|c|c|c|c|}
\hline & & $\begin{array}{l}\text { OHCA in the } \\
\text { workplace }\end{array}$ & $\begin{array}{l}\text { OHCA outside } \\
\text { of the workplace }\end{array}$ & $\begin{array}{l}\text { Adjusted Odds } \\
\text { Ratio }\end{array}$ \\
\hline Age (years) & Mean (SD) & $50.3(10.4)$ & $66.3(19.0)$ & $0.96(0.95-0.98) *$ \\
\hline Gender (female vs male) & N (\%) & $11(18.0 \%)$ & $790(35.3 \%)$ & $0.53(0.26-1.07)$ \\
\hline $\begin{array}{l}\text { Probable cardiac etiology (yes } \\
\text { vs no) }\end{array}$ & $\mathrm{N}(\%)$ & $26(42.6 \%)$ & $852(38.0 \%)$ & $1.06(0.57 .1 .96)$ \\
\hline Witness present (yes vs no) & N (\%) & $46(75.4 \%)$ & $1547(69.1 \%)$ & $1.24(0.64-2.40)$ \\
\hline $\begin{array}{l}\text { Cardiopulmonary } \\
\text { resuscitation performed before } \\
\text { arrival of the emergency team } \\
\text { (yes vs no) }\end{array}$ & $N(\%)$ & $18(29.5 \%)$ & $262(11.7 \%)$ & $2.28(1.23-4.20)^{*}$ \\
\hline $\begin{array}{l}\text { Electric shock delivered by } \\
\text { firemen (yes vs no) }\end{array}$ & $\mathrm{N}(\%)$ & $24(39.3 \%)$ & $325(14.5 \%)$ & $2.50(1.36-4.57) *$ \\
\hline $\begin{array}{l}\text { Intubation by the emergency } \\
\text { physician of the prehospital } \\
\text { care unit (yes vs no) }\end{array}$ & N (\%) & $53(86.9 \%)$ & $1301(58.1 \%)$ & $2.59(1.13-5.94) *$ \\
\hline
\end{tabular}

$S D=$ standard deviation

*Significant $(P<0.05)$ in multivariate analysis. 